\title{
Original Research Article \\ Impact of Pasteurization on Ascorbic Acid in Orange Juice (Overview)
}

\author{
Yuhui Ding \\ University College London, Gower Street, London, PWC1E 6BT
}

\begin{abstract}
Loss in Ascorbic Acid contents of orange juice heated under different situations and $\mathrm{pH}$ was researched. In this experiment, Navanila oranges from Spain were squeezed and filtered by using a vacuum pump to make orange juice samples. These samples were extracted and make up with $0.1 \%$ Formic Acid in HPLC water, HPLC water and phosphate buffer solution $(\mathrm{pH}=6)$. Pasteurization was achieved at 60,65 and $70^{\circ} \mathrm{C}$ over 15,25 and $35 \mathrm{~min}$ period by using the water bath method and cooled to room temperature immediately. After that, Ascorbic Acid contents were analyzed by HPLC and $0.1 \%$ Formic Acid in HPLC water, HPLC water and phosphate buffer solution $(\mathrm{pH}=6)$ were used as mobile phases separately for their solutions. HPLC standard samples of Ascorbic Acid were prepared which means 0.1g Ascorbic Acid was weighted and then diluted into 50-250mg/ L solutions to make calibration lines for three solutions.

The wavelength of Ascorbic Acid was $245 \mathrm{~nm}$ but it changed to $296 \mathrm{~nm}$ when samples in phosphate buffer solution ( $\mathrm{pH}=6$ ). Results showed that Ascorbic Acid concentration is more at $60^{\circ} \mathrm{C}$ at $15 \mathrm{~min}$ and there was a total decline trend with the increase of time and temperature. After statistics analysis, it has a significant affect $(\mathrm{P}<0.5)$ related to Ascorbic Acid contents with temperature and $\mathrm{pH}$. Keywords: Ascorbic Acid; Pasteurization; HPLC; Temperature, Time and pH
\end{abstract}

\section{Introduction}

Orange juice has become one of most popular drinks in beverage industry which revenue in this segment amounts to US $\$ 29,736.5 \mathrm{~m}$ and the average per capita consumption stands at $1.2 \mathrm{~L}$ in 2020 worldwide. The orange juice market is forecast to increase annually by $1.7 \%$ over the $2020-2023$ periods (orange juice worldwide statista, 2020).Considering the composition of orange juice, it was proven that organic acids (e.g. $\mathrm{C}_{6} \mathrm{H}_{8} \mathrm{O}_{7}, \mathrm{C}_{4} \mathrm{H}_{6} \mathrm{O}_{5}$ and $\mathrm{C}_{6} \mathrm{H}_{8} \mathrm{O}_{6}$ ), saccharides (mainly saccharose, glucose, and fructose) and different kinds of phenolic compounds, including hydroxybenzoic acids, hydroxycinnamic acids and flavanones are presence. Ascorbic Acid is a temperature-sensitive molecule based on its chemical structure.

Ascorbic Acid is a kind of water-soluble vitamins that cannot be naturally synthesized in the human body. Ascorbic Acid deficiency can indirectly cause scurvy including bleeding sores, tooth loss, anemia and a reduce rate of healing for injuries (Anitra and Jens, 2017). As for Ascorbic Acid, it can be as an antioxidant promoting collagen synthesis which is a key protein and scurvy will be caused due to lack of collagen (Nicholas et at., 2018). Temperature, time and $\mathrm{pH}$ are three main parameters that effect the content of Ascorbic Acid. Pasteurization is a common heat method in the beverage industry, which is used to reduce the native bacterial and minimum the loss of Ascorbic Acid in order to improve the quality of orange juice by cooling immediately after heating at $60-100^{\circ} \mathrm{C}$ (Luiz and Paul , 2003). Based on different kinds of heat treatment methods, Cinquanta, Albanese et al. (2010) have researched that the effects on orange juice batch pasteurization in an improved pilot-scale microwave oven by heating orange juice at $60,70,75$ and $85^{\circ}$ Cover a time range of 2-8 minutes. Then, they analyzed the loss of some nutrients, such as Ascorbic Acid. Another key parameter of $\mathrm{pH}$ is investigated in a study, written by Priscilla and Sherman in 1977, which researched stability of Ascorbic Acid in orange juice in phosphate buffer solutions at different $\mathrm{pH}$ values over 0-7 day's period. High performance liquid chromatography (HPLC) is a quality and quantity analytical technique. There is a basic principle of HPLC which is the mobile phase and the solution used to make up with orange juice in the experiment.There are two main features in the HPLC report: Retention time and Peak area. HPLC can be used to measure accurately the content of Ascorbic Acid. According to the characteristics of Ascorbic Acid in orange juice, the absorption wavelength is at $245 \mathrm{~nm}$. The HPLC should be set under these conditions: Ultra AQ C18column150mmx4.6mm, mobile phase: 95\% 0.1\% Formic Acid in $\mathrm{H} 2 \mathrm{O}: 5 \% \mathrm{MeOH}$, flow-rate $1 \mathrm{ml} /$ minute, room temperature (Conte et al., 2010). Therefore, the main purpose of this study is that investigate the loss of Ascorbic Acid content under different heat temperature $\left(60,65\right.$ and $\left.70^{\circ} \mathrm{C}\right)$, time $(15,25$ and $35 \mathrm{~min})$ and $\mathrm{pH}$ ( $\mathrm{pH}$ of original juice with HPLC water, buffer solution- $\mathrm{pH}=6$ and $0.1 \%$ Formic Acid) conditions. The method of this study is heating the fresh orange juice at 
different time by a water bath to achieve the set temperature, preparing the Phosphate Buffer Solution to change the $\mathrm{pH}$ conditions, measuring the content of Ascorbic Acid by HPLC. Also, the novel method is that combines temperature, time with $\mathrm{pH}$ parameters during the heating process which shorten time of the experiment and saves costs.

\section{Materials and Methods}

(1) Materials: Navelina oranges were purchased in UK. Squeezed orange by hand. HPLC-grade solvents were obtained from Themo Fisher Scientific including 0.1\% Formic Acid in HPLC water, di-Sodium hydrogen orthophosphate anhydrous, Sodium DiHydrogen OrthoPhosphate Monohydrate ,the standards of Ascorbic Acid .

(2) Equipment: HPLC, 2 ml Luer-Slip Plastic Disposable Syringe (packed per 100 pieces, fisherbrand),2.0ml Screw Vials clear,12*32mm 9-245, Restek Marking Spot,RC 0.45um filter, HPLC Capm, Accumet AE150(Fisher Scientific), Vacuum Gas Pump and bottle(VWR),filter paper, $10 \mathrm{ml}$ Graduated cylinder, $3 * 50 \mathrm{ml}$ beakers, $3 * 20 \mathrm{ml}$ beakers, $1000 \mathrm{ml}$ beaker, $1 \mathrm{~L}$ Volumetric Flask, $3 * 100 \mathrm{ml}$ volumetric flasks, $6 * 10 \mathrm{ml}$ volumetric flasks, $1000 \mathrm{ml}$ glass bottle, $10 \mathrm{ml}$ transfer pipette, heating pot(amicus)

(3) Preparation 1L of Phosphate Buffer $(\mathrm{pH}=6)$

1) $800 \mathrm{ml}$ of distilled water was prepared in a suitable container. 2) $1.9448 \mathrm{~g}$ of Di-Sodium hydrogen orthophosphate anhydrous was added into the solution. 3) 11.91g of Sodium Dihydrogen Phosphate Monohydrate was added into the solution. 4) The solution was transferred into $1 \mathrm{~L}$ volumetric flask and adjusted with distilled water until volume is $1 \mathrm{~L}$. 5) The buffer solution was transferred into $1000 \mathrm{ml}$ glass bottle and tested $\mathrm{pH}$ by using $\mathrm{pH}$ test instrument (Accumet). 6) Labeled it and keep it refrigerated.

(4) Preparation of Orange Juice samples

1) One orange was Squeezed (around $30 \mathrm{ml}$ ) and filtered by vacuum gas pump. 2) The orange solution was set in $50 \mathrm{ml}$ beakers for 2 minutes and pipette $10 \mathrm{ml}$ upper orange juice into $3 * 50 \mathrm{ml}$ beakers respectively and dissolved with $0.1 \%$ Formic Acid in HPLC water, HPLC water and buffer solution $(\mathrm{pH}=6)$ respectively. 3) Solutions were transferred separately into $3 * 100 \mathrm{ml}$ volumetric flasks.

(5) Low thermal pasteurization treatment

$10 \mathrm{ml}$ orange juice samples was placed in a $20 \mathrm{ml}$ beaker and heated in boiling water in $1000 \mathrm{ml}$ beaker by using water bath pot and a digital temperature probe was used to measure temperature for thermal treatment . Timing for thermal treatment started when the water bath reached $60^{\circ} \mathrm{C}, 65^{\circ} \mathrm{C}$ and $70^{\circ} \mathrm{C}$. The sampling time was set 15,25 and $35 \mathrm{~min}$ respectively at each temperature. After thermal treatment, beakers were immediately cooled in ice/water.

(6) Preparation of HPLC standards

1) Preparation a $1 \mathrm{~g} / \mathrm{L}$ solution of Ascorbic Acid from solid. 2) Preparation three types of calibration solution for HPLC

Each type of $1 \mathrm{~g} / \mathrm{L}$ stock solution was pipette and diluted with their solvent including $0.1 \%$ Formic Acid in HPLC water, HPLC water and buffer solution $(\mathrm{pH}=6)$ respectively. Three types of series of calibration standards were prepared in the range of 50-250 $\mathrm{mg} / \mathrm{L}$ in $10 \mathrm{ml}$ volumetric flasks using the glassware and transfer pipette. Using a syringe and syringe filter transfer a small portion of each solution into a HPLC vial and label everything.

(7) HPLC analysis

All samples were set in syringe and passed through syringe filter and cap the vial.All samples were labeled.

\section{Results}

The results were shown as follows.Ascorbic Acid content declined significantly between 15 and $25 \mathrm{~min}$ at each temperature while showed a slight decline trend after this period up to 35min when make up with HPLC water at $\mathrm{pH}: 3.93$. The loss of Ascorbic Acid was more stable at $65^{\circ} \mathrm{C}$ than other two temperature with the increase of time. There were $37.5 \%$ and $25.3 \%$ of Ascorbic Acid contents rising from 60 to $65^{\circ} \mathrm{Cover} 15$ to $25 \mathrm{~min}$ respectively

When samples make up with $\mathrm{pH}=6$, Ascorbic Acid content decreased more significant at $60^{\circ} \mathrm{C}$ than it at $70^{\circ} \mathrm{C}$ while it showed an increasing trend totally at $65^{\circ} \mathrm{C}$ with the increase of time. It meant buffer solution $(\mathrm{pH}=6)$ which could protect Ascorbic Acid content better. At $65^{\circ} \mathrm{C}$, the most residue of Ascorbic Acid is $117.340 .12 \mathrm{mg} / \mathrm{L}$ at $25 \mathrm{~min}$. The most residue of Ascorbic Acid content was $127.620 .96 \mathrm{mg} / \mathrm{L}$ at $15 \mathrm{~min}$ at $60^{\circ} \mathrm{C}$ which showed decrease with the increase of temperature at 15 and $35 \mathrm{~min}$. However, the secondary rank of content was $122.741 \mathrm{mg} / \mathrm{L}$ at $25 \mathrm{~min}$ at $65^{\circ} \mathrm{C}$.Ascorbic Acid Loss became stable with the increase of $70^{\circ} \mathrm{C}$

When samples make up with $\mathrm{pH}=6$, Ascorbic Acid content indicated that decreased significantly from $49.120 .07 \mathrm{mg} / \mathrm{L}$ to $47.580 .43 \mathrm{mg} / \mathrm{L}$ from $15 \mathrm{~min}$ to $35 \mathrm{~min}$ at $60{ }^{\circ} \mathrm{C}$ while it kept stable from 15 to $35 \mathrm{~min}$ at $65^{\circ} \mathrm{C}$ and $70^{\circ} \mathrm{C}$ respectively. The biggest decrease (about 3\%) of Ascorbic Acid was from $49.120 .07 \mathrm{mg} / \mathrm{L}$ to $47.60 .05 \mathrm{mg} / \mathrm{L}$ between from $60^{\circ} \mathrm{C}$ to $65^{\circ} \mathrm{C}$ at $15 \mathrm{~min}$.

\section{Discussion}

According to the result, residual errors would be discussed, including equipment and Ascorbic Acid contents.As for equipment, the residual error was 0.1 for the $10 \mathrm{mLgradual}$ cylinder and $100 \mathrm{~mL}$ for the volumetric flasks. The residual error of Ascorbic Acid contents was based on standard deviation. There was a novel method for analyzing Ascorbic Acid contents in orange juice samples with phosphate buffer solution $(\mathrm{pH}=6)$.

According to characteristics of Ascorbic Acid, it can be easily degraded and oxidized. One major cause is that orange juice samples were not heated in close containers, in which the probability of oxidation would increase.The wavelength of Ascorbic Acid is 296nm, and can be used to determine the Ascorbic Acid in orange juice under the phosphate buffer solution ( $\mathrm{pH}=6$ ). These were then extracted from orange juice and other liquid foods, to research the food quality after heating process.Compared to $0.1 \%$ formic acid with HPLC water, phosphate buffer solution $(\mathrm{pH}=6)$ indicated a minimal loss of Ascorbic Acid about 8.610.96mg/L at $15 \mathrm{~min}$ at $60{ }^{\circ} \mathrm{C}$. However, Ascorbic Acid loss showed a decrease within $15 \mathrm{~min}$ to $25 \mathrm{~min}$, but increased from $25 \mathrm{~min}$ to $35 \mathrm{~min}$ at $65^{\circ} \mathrm{C}$. This may be due to the instability of buffer solution, with changes of temperature and time. Ascorbic Acid is best kept at 
$60^{\circ} \mathrm{C}$ at $15 \mathrm{~min}$ during the heating process, and $\mathrm{pH}$ of orange juice could change to around 6 .

\section{Critical analysis}

The experiment had many limitations.Firstly, the accuracy of the measurement equipment was demonstrated above. Secondly, although the water bath pot could set the temperature of the outer environment,the inner temperature is not accurate.The orange juice samples were then immediately cooled, which cannot be achieved with the same time and temperature.According to Maria et al. (2006), the factor of light exposure was analyzed to accelerate browning in fruit juice, and the greater loss of Ascorbic Acid would increase with the exposure time.They also found that heat and water reduce Ascorbic Acid.This is as Ascorbic Acid can be affected by air, heat and water easily.The other main factor is $\mathrm{pH}$, which not only affects Ascorbic Acid contents during heat process, but also during storage. Changing the $\mathrm{pH}$ of orange juice and removing dissolved oxygen as much as possible during the fruit juice manufacturing process, to reduce the loss of Ascorbic Acid, and extend the best-before date, is a choice.Pasteurization is a key step in the fruit juice industry and these two methods would be benefit for this step.There are two alternative methods for analyzing the content of Ascorbic Acid, which are titrimetric and spectrophotometric. The titrimetric method was used by and iodimetric back-titration (Isam et al., 2017). Compared with HPLC, this method is not as accurate, due to the volume of regents and visual check.

\section{References}

1 Allison Cooke. (2017) 'Dietary Food-Additive Phosphate and Human Health Outcomes.' Journal of Food Science and Food Safety. 16(5). 1541-4337.

2 Anitra C. Carr, and Jens Lykkesfeldt. (2017) Vitamin C in Health and Disease.MDPI St. Alban-Anlage 66 Switzerland: Published online Nutrients.

3 Isam Eldin H. Elgailani, Mohamed A. M. Gad-Elkareem, Elnoor A. A. Noh, Omer E. A. Adam, Ahmed M. A. Alghamdi (2017) 'Comparison of Two Methods for The Determination of Vitamin C (Ascorbic Acid) in Some Fruits.' Journal of Chemistry.2(1). pp. $1-7$.

4 Lanfranco S. Conte, Sabrina Moret, and Giorgia Purcaro. (2010) Handbook of HPLC 2rd. Chromatographic Science Series volume11. Edited by Danilo Corradini. New York: CRC Press.

5 L. Cinquanta, D. Albanese, G. Cuccurullo, and M. Di Matteo. (2010) 'Effect on Orange Juice of Batch Pasteurization in an Improved Pilot-Scale Microwave Oven,' Journal of Food Science, 75(1750). E46-E50.

6 Luiz Trugo and Paul M. Finglas. (2003) The Encyclopeida of Food Sciences and Nutrition, Second Edition. Food Technology and Nutrition. 10(6000). 7-17. Elsevier Science Ltd.: Academic Press.

7 Maria I. Gil, Encarna Aguayo, and Adel A. Kader. (2006) 'Quality Changes and Anutrient Retention in Fresh-Cut versus Whole Fruit during Storage.’ Journal of Agriculture Food Chemistry. 54(12). 4284-4296.

8 Nicholas N. DePhillipo, Zachary S. Aman, Mitchell I. Kennedy, J. P. Begley, Gilbert Moatshe, and Robert F. LaPrade. (2018) 'Efficacy of Vitamin C Supplementation on Collagen Synthesis and Oxidative Stress After Musculoskeletal Injuries: A Systematic Review.' Orthop J Sports Med. 6(10). pp. 3-6. 